\title{
Seasonal Variation in Encounter Rate of Avian Community at Tranquebar Area, Nagapattinam District, Tamil Nadu, India
}

\author{
R.Praveen Kumar, G. Thomas Nithiyanandam
}

\begin{abstract}
Present study was carried out from January 2016 to December 2016 variation in encounter rate of avian community in different habitat and season. Totally 470 sightings of bird species was obtained both morning and evening counts from 360 one kilometer transect walks along the 15 transects. Average of encounter rate was $0.40 \pm 0.05$ (5) birds / $/ \mathrm{km}$ walks. The overall encounter rate was ranged in different habitat from 0.10 to 0.84 and season 0.12 to 0.38 birds/walks. The encounter rate was statistically significant between seasons (Kruskal - Wallis test $\mathrm{H}=12.08, d f=4, P=0.003)$. All habitat and different season 55 species were recorded and majority of bird species found $58 \%$ in agriculture and river bund remaining $42 \%$ in other habitats.
\end{abstract}

Key Words: Habitat, Season, bird, Tranquebar, Tamil Nadu, India

\section{INTRODUCTION}

Species composition of bird community varied in relation to different habitat and season. Population and distribution of bird studies is important tool indicating wealth of ecosystem (Jayson and Mathew 2000). Knowledge of the number in a population of avian community is prerequisite for effective wildlife resources management. The realistic conservation programme cannot be proposed before the basic information is collected therefore, the needed for quantitative, accurate and comprehensive maps of species distribution and abundance.

Indian avifauna is one of the most interesting in the world and provides sample opportunity for further significant research in zoogeography and its related aspects of ecology. The number of habitat variables taken into consideration depends on the objectives of the study and on the attributes of the habitat to which the population under study is responding. Here in, variation in encounter rate of avian species in different habitat and season wise was assessed. Such an investigation would help in understanding their ecological significance in different habitats which could be more useful for its management aspect for conservation.

\section{MATERIALS AND METHODS}

Study Area:

Tranquebar Area is situated in Nagapattinam District of Tamilnadu, India which lie between $11^{\circ} 03^{\prime} 43.40^{\prime} \mathrm{N}$ longitude and 79 $48^{\prime} 37.04^{\prime \prime} E$ latitude. Nagapattinam District is one among 35 District of Tamilnadu, and area covered is
2715.83 sq.km. It is bounded by Bay of Bengal on the east (Meganathan and Jeevanadham 2017). This study area is rich and diverse bird species present. Population and ecological studies have been reported in different organism in different habitat at Tranqubar Taulk (Karunakaran and Jeevanandham 2018, Meganathan and Jeevanadham 2019a). The present study was carried out in Tranquebar Area covering about 50 Sq.km. in different habitats like agriculture, river bund, non-cultivated, groove and human habitation during the study period from January 2016 to December 2016 (Fig-1).

\section{Methods:}

The abundance of bird species using by adapting line transect sampling method. Encounter rate was calculated the number of birds counted on transect. Totally 15 line transect was laid in different habitat in one kilometer length. The number of transects depends upon the area of each habitat in which five in agriculture, four in river bund, two in groove, two in non-cultivated and two in human habitation transect were laid. The Agriculture and river bund habitat were larger than the other habitat hence five and four transect were laid. All the transects were sampled immediately after the Sun rise and normally from 0600h to $0800 \mathrm{~h}$ and before the Sun set $1600 \mathrm{~h}$ to $1800 \mathrm{~h}$ both morning and evening with normal speed of walk $(0.75$ to $1.00 \mathrm{~km} / \mathrm{hr}$.). The birds were observed by 7 X50 Binocular (Olympus) throughout the study period. A group of birds was considered as a single individual and only one perpendicular distance to the middle of the flock was measured. Bird species was identified using a handbook of the birds by Ali and Ripley (1987). Totally, 15 transects of one km length were walked every month in the study period. A total of 360 transect walks were made in throughout study period.

Revised Manuscript Received on September 10, 2019.

R.Praveen Kumar, Department of Zoology, T.B.M.L.College, Porayar, Tamilnadu, India

(E-mail: brightsonsittan@gmail.com)

G. Thomas Nithiyanandam, Department of Zoology, T.B.M.L.College, Porayar, Tamilnadu, India 
Figure-1. Showing the different habitat viz., agriculture, river bund, non-cultivated, groove and human habitation during the study period.

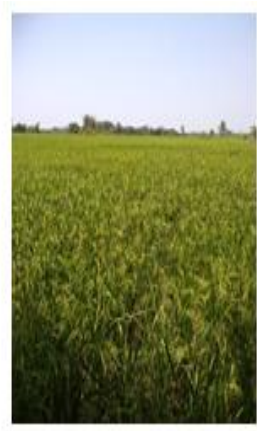

Agriculture

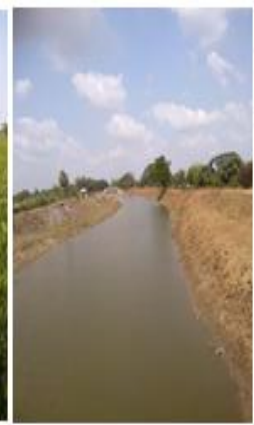

River bund



Groove
Non Cultivated
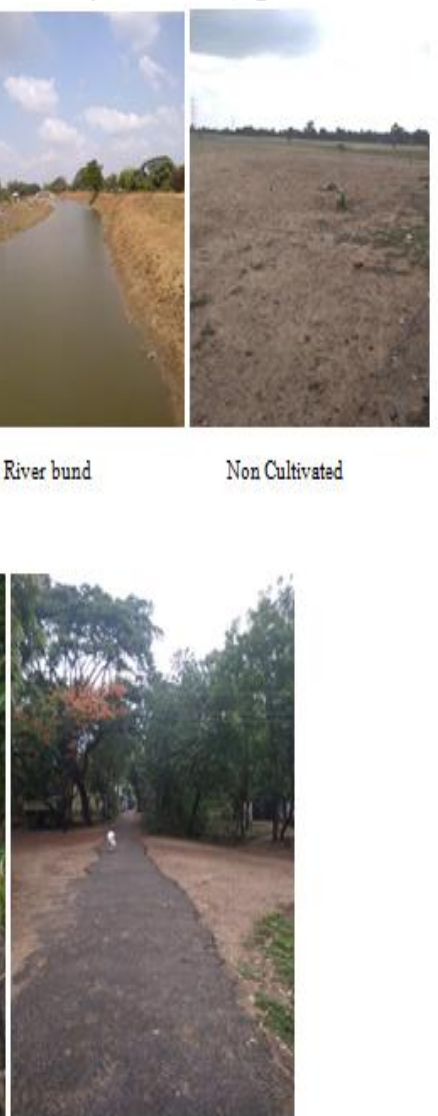

Human habitation
Data Analysis:

A comparison was made among habitats and seasons with appropriate statistical analysis. Univariate statistical analysis of Kruskal-Wallis one-way Analysis ANOVA was tested among habitats and seasons.

\section{RESULTS AND DISCUSSIONS}

\section{Encounter rates in different habitat:}

Totally 470 sightings of bird were obtained in both morning and evening counts. A total of 270 man hours were spent for population count of avian community from January 2016 to December 2016. The overall encounter rate was ranged from 0.18 to $0.75 \mathrm{birds} / \mathrm{km}$ walk in different habitat. Higher encounter rate of bird species was recorded in agriculture $0.75 \pm 0.06$ birds $/ \mathrm{km}$ walk (Table 1 ). Low encounter rate was obtained from human habitation. The higher number of avian species in agriculture habitat is due to variety of agricultural crops, vegetation densities and availability of bushes and herbs and shrubs for foraging and nesting. Further, presence of insects, cereals, low grass cover, less human disturbances and more clearings were responsible for the high density of avian species in agriculture. Ramesh and McGowan (2009) reported that birds prefers habitats with mixed patches of forest and open lands and roosts at tall trees. Such lowest density of avian (2011) recorded in other galliformes species of Gallus sonneratti at Gudalur Range of Theni forest division. species in human habitation was observed by Ramesh et al.,

Table 2. Encounter rates of avian species (Birds/km walk) in different habitats at Tranquebar area

\begin{tabular}{|l|l|l|l|}
\hline Habitat & $\mathbf{N}$ & $\begin{array}{l}\text { Encounter } \\
\text { rate } \mathbf{\pm} \text { SE) } \\
\text { birds/km } \\
\text { walks }\end{array}$ & $\begin{array}{l}\text { Encounter } \\
\text { rate at 95\% } \\
\text { CI birds/km } \\
\text { walks }\end{array}$ \\
\hline Agriculture & 215 & $0.84 \pm 0.04$ & $0.72-0.96$ \\
\hline River bund & 109 & $0.52 \pm 0.08$ & $0.40-0.67$ \\
\hline Groove & 65 & $0.33 \pm 0.05$ & $0.20-0.45$ \\
\hline $\begin{array}{l}\text { Non- } \\
\text { Cultivated } \\
\text { land }\end{array}$ & 70 & $0.25 \pm 0.05$ & $0.13-0.38$ \\
\hline $\begin{array}{l}\text { Human } \\
\text { habitation }\end{array}$ & 11 & $0.10 \pm 0.04$ & $0.02-0.21$ \\
\hline
\end{tabular}

$\mathrm{CI}=$ Confidence Interval, $\mathrm{SE}=$ Standard Error, $\mathrm{N}=$ number of sightings

\section{Encounter rates in different seasons:}

Seasonal variations in the encounter rate of avian community in pre-monsoon, monsoon, post-monsoon and summer seasons are given in Table 2 . The encounter rate for avian species varied from $0.21 \pm 0.05 \mathrm{birds} / \mathrm{km}$ walk in premonsoon to $0.38 \pm 0.05 \mathrm{birds} / \mathrm{km}$ walk in post-monsoon in 2016. The encounter rate between months among seasons were statistically not significant $(\mathrm{F}=0.540, \mathrm{df}=3, \mathrm{P}=$ $0.315)$. However, the encounter rate statistically significant between seasons (Kruskal-Wallis $\mathrm{H}=12.08$, df, $4 \mathrm{P}<0.003$ ). Seasonal variation in the encounter rates of avian species were recorded with the monsoon and post monsoon season was high densities and pre-monsoon and summer season was low densities. Many studies have been reported on seasonal variations in avian species (Caula et al.2008, Girma et al.2017). The results of the present study revealed a seasonal variation pattern by bird, basically depending on the needs of breeding activity and seasonally coming up of bushes which played important role.

Table 2. Encounter rates of avian species (Birds/km walk) among seasons at Tranquebar area

\begin{tabular}{|l|l|l|l|}
\hline Seasons & N & $\begin{array}{l}\text { Encounter } \\
\text { rate } \mathbf{\pm} \text { SE) } \\
\text { birds/km } \\
\text { walks }\end{array}$ & $\begin{array}{l}\text { Encounter } \\
\text { rate at 95\% } \\
\text { CI birds/km } \\
\text { walks }\end{array}$ \\
\hline $\begin{array}{l}\text { Pre- } \\
\text { Monsoon } \\
\text { (June-Aug) }\end{array}$ & 152 & $0.21 \pm 0.05$ & $0.10-0.28$ \\
\hline $\begin{array}{l}\text { Monsoon } \\
\text { (Sept-Nov) }\end{array}$ & 118 & $0.35 \pm 0.08$ & $0.23-0.46$ \\
\hline $\begin{array}{l}\text { Post- } \\
\text { Monsoon } \\
\text { (Dec-Feb) }\end{array}$ & 95 & $0.38 \pm 0.05$ & $0.28-0.50$ \\
\hline $\begin{array}{l}\text { Summer } \\
\text { (March- } \\
\text { May }\end{array}$ & 105 & $0.25 \pm 0.05$ & $0.17-0.36$ \\
\hline
\end{tabular}

$\mathrm{CI}=$ Confidence Interval, $\mathrm{SE}=$ Standard Error, $\mathrm{N}=$ number of sightings 


\section{Species distribution:}

Totally 55 species were recorded in overall habitat and majority of species found in agriculture and river bund habitat $53 \%$ (Fig-2). Tranquebar area and surrounding villages are agriculture area, which provide habitat for many waterbirds particularly large wading birds (Meganathan and Jeevanandham 2019b). Lowest species $8 \%$ was recorded in Human habituation. Considerably development was found in Tranquebar area and increasing the urbanization. This is result affecting natural habitat for bird species and many trees removed in human habitationtherefore avifauna forced to settle down into new habitat these result dramatically decrease the bird population (Vitouserk et al.1997).

Figure-2. Showing a species distribution of different habitat.

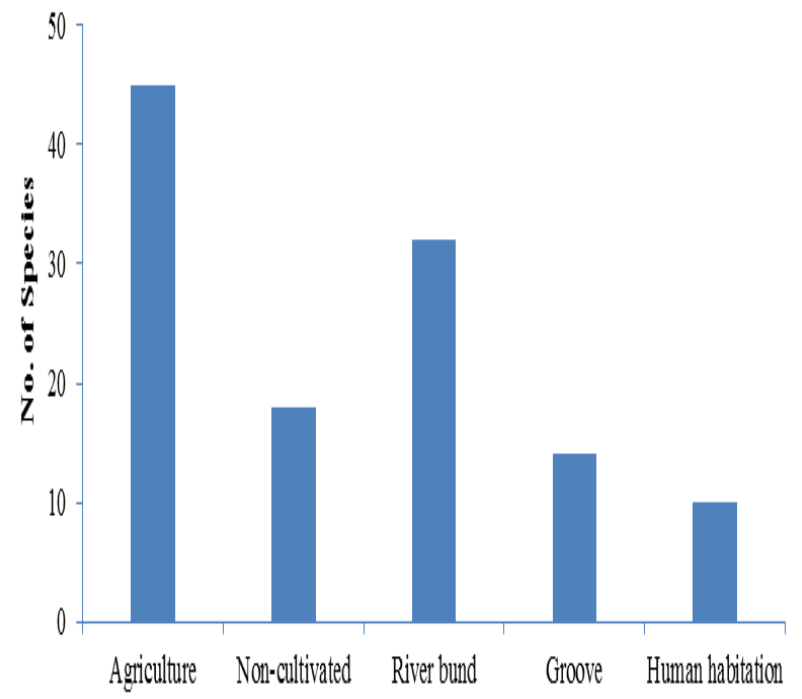

Type of Habitats

\section{CONCLUSION}

Present study concluded that increase the human population and urbanization in this region, the quality of avifauna habitat loss. Therefore, birds are preferred that the alternate habitat. Further studies needed in relation to habitat selection and bird population.

\section{ACKNOWLEDGEMENT}

We thank the Principal and HOD Department of Zoology T.B.M.L. College, Porayar for providing facilities and support to do this research work.

\section{REFERENCE}

1. Ali, S and Ripley, S.D. 1987. Handbook of birds of India and Pakistan. India, Delhi: Oxford University of press. 1-224pp.

2. Caula, S., Marty .P and Martin. J.L. 2008. Seasonal variation in species composition of an urban birds community in Mediterranean France. Landscape and Urban Planning 87:1-9.

3. Girma .Z., Mamo.Y., Mengesha .G., Varma. A. and Asfaw.T, 2017. Seasonal abundance and habitat use of birds species in and around Wondo Genet Forest, South-central Ethiopia Ecology and Evolution 7:3397-3405.

4. Jayson, E.A. and Mathew, D.N., 2000. Diversity of species abundance distribution of birds in the tropical forestof Silent Valley, Kerala. Journal of Bombay Natural History and Society. 97 (3)390:399.
5. Karunakaran.K and Jeevanandham. P. 2018. Studies on the Influence of Temperature in Aquatic Anuran Population in Cauvery Delta Region of Tranquebar Taluk of Nagapattinam District, Tamil Nadu, India. International Journal of Pharmaceutical and Biological Archives. 9 (4):225-259.

6. Meganathan.T,.andP.Jeevanandham. 2017. Seasonal and Spatial Variation of Flock Size of Asian Openbill Stork Anastomus oscitens at Foraging Site in Nagapattinam District, Tamilnadu. India. International Journal of Advanced Scientific Research and Development (IJASRD).04(11):56-62

7. Meganathan.T,.andP.Jeevanandham.2019a.Prey and Prey size selection of Asian Openbill Stork Anastomus oscitens in Sembanarkoil region at Nagapattinam District. Tamilnadu. India International Journal of basic and applied research. 9 (9):132-140.

8. Meganathan, T., P. Jeevanandham, 2019b. Population size and feeding habitat preference of Asian Openbill Stork Anastomus oscitans in relation to availability of prey at Sembanarkoil region, Nagapattinam District, Tamilnadu, India. Journal of Emerging Technologies and Innovative Research (JETIR). 6 (4):257-263

9. Ramesh,N., Sathyanarayanan, M.C. and Lloyd H.2011.Abundance of Grey Jungle Fowl (Gallus sonneratii) at Theni Forest Division, Western Ghats, India: implication for monitoring and conservation. International Journal of Galliformes conservation. 2:14-21.

10. Ramesh, K. and McGowan,P. 2009. On the current status of Indian Pea Fowl Pavo cristatus (Aves: Galliformes: Phasianidae): keeping the common species common. Journal of Threatened Taxa.1:106-108.

11. Vitousek, P.M., Mooney, H.A., Lubchenco, J. and Melillo, J.M. 1997. Human domination of Earth"s eco-system. Science 227, 494-499. 